\title{
Correlations between Expression of Ki67 with Her-2 and P53 Tumour Markers in Breast Cancer Patients
}

\author{
R Sheikhpour, F Poorhosseini
}

\begin{abstract}
Introduction: Breast cancer is the most common cancer in women. The importance of several molecular markers in breast cancer has generated interest in recent years. The assessment of biomarkers such as Ki67, Her-2 and P53 can be valuable in predicting the outcomes of diseases and decision-making for their optimal treatment. The purpose of this study is to investigate the relationships among Ki67, Her-2 and P53 tumour markers in breast cancer patients.

Subjects and methods: In this study, 184 breast cancer patients were chosen. Immunohistochemistry technique was used for detecting the expressions of Ki67, Her-2 and P53 proteins in breast cancer patients. For the correlations among the parameters, Fisher exact test and Spearman's rho were used. In all the tests, the p-value was considered significant if it were less than 0.05 .

Results: In this study, Ki67 positive, P53 and Her-2 positive, were found, respectively in $53.2 \%, 38.5 \%$ and $54.6 \%$ of the patients. There was a significant relationship between Ki67 and P53 ( $<<0.05)$. But, there were no relationships among Ki67 and Her-2 and the clinicopathological parameters ( $>0.05)$.

Conclusion: Breast cancer progression is often associated with the alterations in the expressions of Ki67, P53 and Her-2 tumour markers. These changes may affect the treatment decisions. Also, the significant relationship between Ki67 and P53 protein showed that cell proliferation may be related to the over-expression of $P 53$ protein in breast cancer patients.
\end{abstract}

Keywords: Breast cancer patients, Her-2, Ki67, P53

\section{Correlaciones entre las Expresiones de Ki67, Her-2 y los Marcadores de Tumor P53 en Pacientes con Cáncer de mama}

\author{
R Sheikhpour, F Poorhosseini
}

\begin{abstract}
RESUMEN
Introducción: El cáncer de mama es el cáncer más común en las mujeres. La importancia de varios marcadores moleculares en el cáncer de mama ha generado interés en los últimos años. La evaluación de biomarcadores como el Ki67, Her-2 y P53 puede ser valiosa en la predicción de los resultados de las enfermedades y la toma de decisiones para su tratamiento óptimo. El propósito de este estudio es investigar las relaciones entre los marcadores tumorales Ki67, Her-2 y P53 en los pacientes con cáncer de mama.

Sujetos y métodos: En este estudio, se seleccionaron 184 pacientes de cáncer de mama. Se utilizó la técnica de inmunohistoquímica para la detección de las expresiones de las proteinas Ki67, Her-2, y P53 en pacientes con cáncer de mama. Para las correlaciones entre los parámetros, se utilizaron el test exacto de Fisher y la Rho de Spearman. En todas las pruebas, el valor $p$ se consideraba significativo si era menor de 0.05 .

Resultados: En este estudio, Ki67 positivo, P53 y Her-2 positivos, fueron encontrados, respectivamente en 53.2\%, 38.5\% y 54.6\% de los pacientes. Hubo una relación significativa entre el Ki67 y P53 (p < 0.05). Pero no hubo relación entre Ki67 y Her-2 y los parámetros clínico-patológicos ( $\mathrm{p}>0.05$ ).
\end{abstract}

From: ${ }^{1}$ Hematology and Oncology Research Center, Shahid Sadoughi University of Medical Sciences, Yazd and ${ }^{2}$ Kerman University of Medical Science, Kerman, Iran.
Correspondence: Dr R Sheikhpour, Hematology and Oncology Research Center, Shahid Sadoughi University of Medical Sciences, Yazd, Iran. Fax: 00983516235958, email: Robab.sheikhpour@iauyazd.ac.ir 
Conclusión: La progresión del cáncer de mama a menudo se asocia con las alteraciones en las expresiones de los marcadores tumorales Ki67, P53 y Her-2. Estos cambios pueden afectar las decisiones de tratamiento. También, la significativa relación entre las proteínas Ki67 y P53 demostró que la proliferación celular puede estar relacionada con la sobre-expresión de la proteína P53 en pacientes con cáncer de mama.

Palabras claves: Pacientes con cáncer de mama, Her-2, Ki67, P53

West Indian Med J 2017; 66 (1): 79

\section{INTRODUCTION}

Breast cancer is the most common cancer in women (1), accounting for approximately one-third of all the illnesses in women (2). It affects one out of every eight women in the United States of America. Also, it is one of the most frequent malignancies among Iranian women (3). To determine the severity of the disease and how to treat these patients, several factors such as, tumour size, lymph node involvement, pathological type, stage etc should be evaluated (3). One of the tools used in the determination and the diagnosis of this invasive disease is the evaluation of tumour marker status in breast cancer patients.

Recent studies have shown the significance of tumour markers in breast cancer patients. The assessment of these biomarkers with immunohistochemical technique (IHC) is valuable in predicting the outcomes of diseases and decisionmaking for their optimal treatment (4). Tumour markers are protein-derived tumour tissues that can be measured in tissue samples or serum in patients.

$\mathrm{Ki}-67$, a nuclear marker of cell proliferation, recognizes a nuclear antigen present only in proliferating cells in G1, S, $\mathrm{G} 2$ and $\mathrm{M}$ phases (5) and its half-life has been estimated at around 60 to 90 minutes (6). High levels of Ki67 in breast cancers are associated with worse outcomes (7). Ki67 is not included in routine clinical decision-making because of a lack of clarity regarding how Ki67 measurements should influence clinical decisions (8).

P53 is a known tumour suppressor gene $(9-15)$ on chromosome 17 (16-19). P53 gene codes $53 \mathrm{KD}$, a nuclear phosphoprotein (20-22) that plays an important role in many critical cellular events related to human ageing and cancer (23), including, DNA damage (24), telomere shortening and oxidative stress (23). Unlike normal P53, non-functional mutated P53 accumulates in the nucleus of tumour cells that can be detected by immunohistochemical analyses. Multiple studies have shown that P53 over-expression in breast cancer is associated with a worse outcome (24).

Human epidermal growth factor receptor-2 (Her-2) is over-expressed in approximately $15 \%$ to $25 \%$ of breast cancers $(25,26)$. It appears that Her- 2 over-expression can be correlated with the resistance to hormonal therapy, sensitivity to anthracycline-based chemotherapy and resistance to cyclophosphamide, methotrexate and 5-fluorouracil [CMF] (27). Her-2 encodes a $185-\mathrm{kDa}$ transmembrane glycoprotein with intracellular tyrosine kinase activity that belongs to the epi-dermal growth factor receptor family (25).

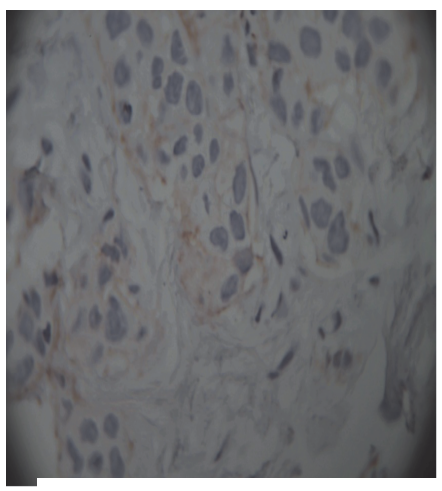

A: $\quad$ Ki67 negative $(100 \mathrm{x})$

A: No/ / negauve (100 $\mathrm{x}$ )

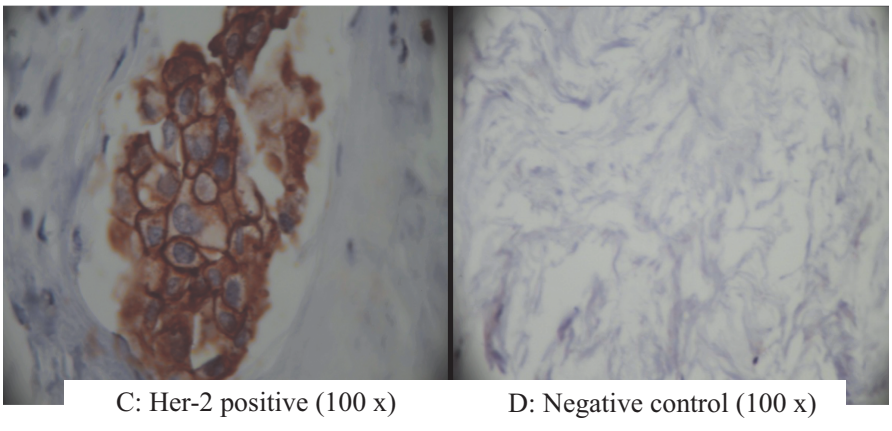

Figure: The immunohistochemical expressions of Ki67, Her-2 and P53 proteins in the breast cancer patients. (A) Ki67 negative, (B) p53 positive, (C) Her-2 positive and (D) negative control.

Despite extensive research on molecular markers in relation to breast cancer, the observed differences in the results and the effects of demographic factors on the status of biomarkers had been noted in different regions. Therefore, the purpose of this study was to evaluate the relationships among Ki67, Her-2 and P53 tumour markers in Iranian women with breast cancer.

\section{SUBJECTS AND METHODS}

\section{Study population}

In this study, 184 cases of women with mammary carcinoma were chosen from the hospitals in Yazd city from 2012 to 2014 in central Iran and studied in Yazd Research and Clinical Centre for Infertility after receiving their consent. Additionally, 
the Ethics Committee and Research Committee of Yazd Research and Clinical Centre for Infertility approved this study.

\section{Histopathological analysis}

In this study, the biopsy specimens were fixed in $10 \%$ neutral buffer formalin; then, they were placed in graded concentrations of $70 \%, 80 \%, 90 \%$ and $100 \%$ alcohol. We then put them in xylene and paraffin in automatic tissue processors. Following the fixation, the specimens were embedded in paraffin wax and sliced to $4 \mu \mathrm{m}$ in thickness for staining. For the staining and examination of the tissue sections, haematoxylin and eosin (H \& E) were used. The histological grade of the tumour was determined using Bloom and Richardson classification modified by Elston $(28,29)$.

\section{Immunohistochemical method}

Immunohistochemical method was performed on the specimens that were embedded in the paraffin wax from the main tumours. In summary, poly-L-lysin-coated slides were chosen and $4 \mu \mathrm{m}$ thick histological sections were mounted on them. Then, slides were dewaxed with xylene and rehydrated with decreasing intensity of alcohol. For blocking endogenous peroxidase activity, the sections were treated with $3 \%$ hydrogen peroxide for 15 minutes. The slides were transferred to citrate buffer and boiled for 15 minutes in a microwave oven for antigen retrieval. The sections were washed three times with phosphate buffered saline. After blocking non-specific binding sites, the sections were exposed to primary antibody for one hour (Table 1).

Table 1: Primary antibody used in the immunohistochemical staining of tumour markers in breast cancer patients

\begin{tabular}{lcc}
\hline Isotype & Dilution & Source \\
\hline $\begin{array}{l}\text { Monoclonal mouse anti human } \\
\text { DO7 }\end{array}$ & Ready for use & Dako \\
$\begin{array}{l}\text { Monoclonal mouse anti human } \\
\text { MIB-1 }\end{array}$ & Ready for use & Dako \\
$\begin{array}{l}\text { Polyclonal rabbit anti human } \\
\text { c-erbB2 }\end{array}$ & $1: 400$ & Dako \\
\hline
\end{tabular}

After washing with PBS, the slides were exposed to Horseradishperoxidas conjugated anti-mouse, anti-rabbit Ig (Ebnesina, Iran). The slides were washed with PBS and incubated with 3, 3-diamino-benzidine tetrahydrochloride (Sigma). The sections were counterstained with haematoxylin and rinsed in tap water. Next, they were immersed in graded alcohol, xylene and finally mounted. Negative control was performed by the replacement of the primary antibody with fetal bovine serum in each series.

\section{Statistical analyses}

Statistical analyses were performed using SPSS software19 version. For the relationships among the parameters, Fisher exact test was used. For measuring the coefficient of concor- dance between two variables, Spearman's rank correlation coefficient (Spearman's rho) was used, $p$-value $<0.05$ was considered to be statistically significant.

\section{RESULTS}

In this study, 184 breast cancer patients were chosen. The mean age of the patients was $51.5 \pm 14.7$ years. The characteristics of the patients are shown in Table 2.

Table 2: Characteristics such as histological type, grade, lymph nodes metastasis and age of breast cancer patients

\begin{tabular}{lrc}
\hline Patients characteristics & $(\mathbf{n}=\mathbf{1 8 4})$ & Percentage \\
\hline Histological type & & \\
Infiltrating ductal carcinoma & 158 & 85.8 \\
Invasive ductal carcinoma & 3 & 1.6 \\
Infiltrating lobular carcinoma & 15 & 8.15 \\
Medullary carcinoma & 4 & 2.1 \\
Missing system & 4 & 2.1 \\
& & \\
Nuclear grades & & \\
1 & 11 & 5.97 \\
2 & 86 & 46.7 \\
3 & 40 & 21.7 \\
Missing system & 47 & 25.5 \\
& & \\
Lymph node metastasis & & \\
Involved & 80 & 43.4 \\
Not involved & 93 & 50.54 \\
Missing system & 11 & 5.9 \\
& & \\
Age & & 39.02 \\
$\leq 40$ & 72 & 60.86 \\
> 40 & 112 & \\
Tumour size & & 22.28 \\
$\leq 3$ Cm & & 51.08 \\
> Cm & 41 & 26.63 \\
Missing value & 94 & \\
\hline
\end{tabular}

\section{Scoring}

Ki67 staining was categorized as positive or negative. The positive staining was considered $>20$ per cent of the cell nuclei. P53 staining was categorized as positive or negative. The positive staining was considered $>5$ per cent of the cell nuclei. Her-2 staining was categorized positive and negative. Positive staining was considered $\geq 1$ per cent. The frequencies and percentages of biomarkers in the breast cancer patients are shown in Table 3.

The result of this study showed that there was a significant correlation between Ki67 and P53 $(p<0.05)$; the coefficient of concordance was 0.18 . But there was no significant correlation between Ki67 and Her-2 $(p>0.05)$. Similarly, there were no significant correlations among Ki67 and Her-2 and P53 ( $p>0.05)$. Table 4 shows the correlations among the biomarkers in the breast cancer patients.

The relationships among the tumour markers and grade, lymph node metastasis and tumour sizes are shown in Table 5 . 
Table 3: Frequencies and percentages of biomarkers in the breast cancer patients

\begin{tabular}{lcc}
\hline Biomarker & Frequencies & Percentages \\
\hline P53 & & \\
Positive & 71 & 38.58 \\
Negative & 98 & 53.2 \\
Missing value & 15 & 8.15 \\
& & \\
Ki67 & 98 & 53.2 \\
Positive & 75 & 40.7 \\
Negative & 11 & 5.9 \\
Missing value & & \\
Her-2 & 100 & 54.6 \\
Positive & 83 & 45.1 \\
Negative & 1 & 0.5 \\
Missing value & & \\
\hline
\end{tabular}

Table 4: Correlations among biomarkers in the breast cancer patients

\begin{tabular}{lcc}
\hline Biomarkers & $\begin{array}{c}\text { Ki-67 } \\
\boldsymbol{p} \text {-value }\end{array}$ & $\begin{array}{c}\text { P53 } \\
\boldsymbol{p} \text {-value }\end{array}$ \\
\hline P53 & 0.022 & - \\
Ki67 & - & 0.022 \\
Her-2 & 0.198 & 0.07 \\
\hline
\end{tabular}

Table 5: Correlations among tumour markers and grade, lymph nodes metastasis and tumour sizes

\begin{tabular}{lccc}
\hline Biomarker & $\begin{array}{c}\text { Lymph Nodes } \\
\boldsymbol{p} \text {-value }\end{array}$ & $\begin{array}{c}\text { Grade } \\
\boldsymbol{p} \text {-value }\end{array}$ & $\begin{array}{c}\text { Tumour sizes } \\
\boldsymbol{p} \text {-value }\end{array}$ \\
\hline $\begin{array}{l}\text { Ki67 } \\
\text { Positive: } 56.6 \%\end{array}$ & 0.35 & 0.085 & 0.09 \\
Negative: $43.35 \%$ & & & \\
Her2 & 0.51 & 0.28 & 0.21 \\
Positive: $54.6 \%$ & & & \\
Negative: $45.3 \%$ & & & \\
P53 & 0.052 & 0.052 & 0.39 \\
Positive: 43.02 & & & \\
Negative: 57.98 & & & \\
\hline
\end{tabular}

The results of this study showed that there were no correlations among the tumour markers and grade, lymph node metastasis and tumour sizes in the breast cancer patients $(p>$ $0.05)$.

\section{DISCUSSION}

The over-expressions of Ki67 protein have been shown in more than $20 \%-50 \%$ of cells that are at high-risk of developing the recurrent disease (30). The measurement of Ki-67 level is a widely used method to assess tumour proliferation (7). $\mathrm{Ki}-67$ expression in breast cancer tissue may be an effective factor for predicting the response to chemotherapy or mixed chemohormonal therapy (6) and may indicate a poor prognosis factor (7). Therefore, Ki-67 expression should be carefully analysed as a routine biological marker in breast cancer patients, especially in those who are candidates for neoadjuvant chemotherapy. Tumours with a higher level of cell proliferation might respond better to chemotherapy than tumours with a lower proliferation (7) and reduced proliferation of Ki67 with chemotherapy may be at least partly due to increased apoptosis (6). In this study, Ki67 positivity was detected in 53.2 per cent of the breast cancer patients; but other studies have shown different results $(31,32)$. This difference might be due to genetic differences; however, other factors, like the threshold for positivity, are responsible for at least some of the differences (33).

Also, there are some controversies on the relationship between Ki-67 expression and P53 protein in cancer patients. Gurzu et al reported that there was no correlation between Ki67 and P53 protein in cancer patients (34). But another study, which is consistent with our study, showed that Ki67 was correlated with P53 protein (35). Therefore, it seems that P53 protein expression may be related to cell proliferation. Double positivity for P53 and Ki-67 expressions in patients, seemed to indicate a higher probability of metastases than single markers. P53 and Ki-67 protein expressions reflect an aggressive disease phenotype with rapid tumour growth (36). It is conceivable that tumours with a worse outcome may have a higher proliferation index with Ki-67 and a higher probability of mutation in tumour suppressor genes, such as P53 (24). This may be one of the main mechanisms in the development of carcinoma (37).

Another study showed that Ki67 was more important than $\mathrm{P} 53$ protein in the prognosis of the breast cancer patients. The prognostic value of Ki-67 over P53 may be due to its significant association with higher nodal metastasis (24). Jeong and et al finding is consistent with our study's finding for they did not observe any correlation between Her-2 and Ki67 (24). Her-2+/Ki-67+ expression was associated with an increased risk of ductal carcinoma in situ recurrences, independent of grade and age of patients (38). A lower expression of Her2/neu and Ki67 in breast carcinoma could implicate a low degree of malignant behaviour (39). Another study showed that the expression of proliferative antigen $\mathrm{Ki}-67$ and/or P53 protein were correlated with the tumour grading (40). But, our study did not show this correlation. It seems that the differences in the degree of grade and sample size of the breast cancer patients could have accounted for the observed differences (8).

\section{CONCLUSION}

This study's findings showed that breast cancer progression is often associated with the alterations in the expressions of Ki67, P53 and Her-2 markers. These changes may affect the treatment decisions. Likewise, the significant relationship between Ki67and P53 protein showed that cell proliferation may be related to the over-expression of P53 protein in this study's breast cancer patients. 


\section{REFERENCES}

1. Wang YA, Johnson SK, Brown BL, Carragher LM, Sakkaf KL, Royds JA et al. Enhanced anticancer effect of a phosphatidylinositol-3 kinase inhibitor and doxorubicin on human breast epithelial cell lines with different p53 and oestrogen receptor status. Int J Cancer 2008; 123: 1536-44.

2. Richie RC, Swanson JO. Breast cancer: a review of the literature. J Insur Med 2003; 35: 85-101.

3. Mousavi SM, Montazeri A, Mohagheghi MA, Jarrahi AM, Harirchi I, Najafi $\mathrm{M}$ et al. Breast cancer in Iran: an epidemiological review. Breast J 2007; 13: 383-91.

4. Nishimura R, Osako T, Okumura Y, Tashima R, Toyozumi Y, Arima N. Changes in the ER, PgR, HER2, p53 and Ki-67 biological markers between primary and recurrent breast cancer: discordance rates and prognosis. World J Surg Oncol 2011; 9: 131.

5. Lebe B, Tuna B, Sis B, Yorukoglu K, Kargi A. Mdm2 and p53 expressions and Ki-67 proliferative index in fibrohistiocytic tumors. Aegean Pathol J 2004; 1: 39-46.

6. Urruticoechea A, Smith IE, Dowsett M. Proliferation Marker Ki-67 in early breast cancer. J Clin Oncol 2005; 23: 7212-20.

7. Kim II Kwan, Kyung Hee Lee, Tae Ryung Kim, Yong Soon Chun, Tae Hoon Lee, Heung Kyu Park. Ki-67 as a Predictor of Response to Neoadjuvant Chemotherapy in Breast Cancer Patients. J Breast Cancer 2014; 17: 40-6.

8. Maggie CU, Cheang SK, Chia DV, Gao D, Leung S, Snider J et al. Ki67 Index, HER2 Status, and Prognosis of Patients with Luminal B Breast Cancer. J Natl Cancer Inst 2009, 101: 20

9. Peterson LF, Mitrikeska E, Giannola D, LuiY, Sun H, Bixby D et al. p53 stabilization induces apoptosis in chronic myeloid leukemia blast crisis cells. Leukemia 2011; 25: 761-9.

10. Bergh J. Clinical studies of p53 in treatment and benefit of breast cancer patients. Endocr Relat Canc 1999; 6: 51-9.

11. Simpson JF, Page DL. The p53 tumor suppressor gene in ductal carcinoma in situ of the breast. Am J Pathol 2000; 156: 5-6.

12. Plesan D, Georgescu V, Patrana N, Plesan C, Stoica D. Immunohistochemical study of p53 and Ki67 in a group of patients with mammary carcinoma. Rom J Morphol Embryol 2010; 51: 459-65.

13. Breen L, Heenan M, Amberger-Murphy V, Clynes M. Investigation of the role of p53 in chemotherapy resistance of lung cancer cell lines. Anticancer Res 2007; 27: 1361-4.

14. Goldschneider D, Horvilleur E, Plassa FL, Guillaud-Bataille M, Million $\mathrm{K}$, Wittmer-Dupret $\mathrm{E}$ et al. Expression of C-terminal deleted p53 isoforms in neuroblastoma. Nucleic Acids Res 2006; 34: 5603-12.

15. Wehmuth Ch, Monteiro Santos E, Wernek RNI, Augusto Soares F. p53 and p21 Immunohistochemistry in colorectal cancer: clinical and pathological correlation in 128 cases. Appl Cancer Res 2006; 26: 21-6.

16. Rahko E, Blanco G, Soini Y, Bloigu R, Jukkola A. A mutant TP53 gene status is associated with a poor prognosis and anthracycline-resistance in breast cancer patients. Eur J Canc 2003; 39: 447-53.

17. Cerrato JA, Yung WK, Liu TJ. Introduction of mutant p53 into a wildtype p53-expressing glioma cell line confers sensitivity to Ad-p53induced apoptosis. Neuro Oncol 2001; 3: 113-22.

18. Schiller JH, Adak S, Feins RH, Keller SM, Fry WA, Livingston RB et al. Lack of prognostic significance of p53 and K-ras mutations in primary resected non-small-cell lung cancer on E4592: a laboratory ancillary study on an eastern cooperative oncology group prospective randomized trial of postoperative adjuvant therapy. J Clin Oncol 2001; 19: 448-57.

19. Horne GM, Anderson JJ, Tiniakos DG, McIntosh GG, Thomas MD, Angus B et al. p53 protein as a prognostic indicator in breast carcinoma: a comparison of four antibodies for immunohistochemistry. Br $\mathrm{J}$ Canc 1996; 73: 29-35.

20. Ageenko AI, Erkhov VS, Cherniaev LV, Volkova Liu. A possible role of phosphoprotein p53 in the mechanism of autostimulation of tumor cell proliferation. Eksp Onkol 1990; 12: 35-7.

21. Kerns BJ, Jordan PA, Moore MH, Humphrey PA, Berchuck A, Kohler $\mathrm{ME}$ et al. p53 over expression in formalin-fixed, paraffin-embedded tissue detected by immunohistochemistry. J Histochem Cytochem 1992; 40: $1047-51$
22. Doosti A, Ghasemi DP, Davoudi N. A p53 codon 72 polymorphism associated with breast cancer in Iranian patients. African J Pharm Pharmacol 2011; 5: 1278-81.

23. Gu J, Spitz MR, Zhao H, Lin J, Grossman HB, Dinney CP et al. Roles of tumor suppressor and telomere maintenance genes in cancer and agingan epidemiological study. Carcinogenesis 2005; 26: 1741-7.

24. Jeong SH, Cao D, Molberg KH, Sarode VR, Rao R, Sutton LM et al. Hormone receptor status rather than HER2 status is significantly associated with increased $\mathrm{Ki}-67$ and p53 expression in triple-negative breast carcinomas, and high expression of Ki-67 but not p53 is significantly associated with axillary nodal metastasis in triple-negative and high-grade non-triple-negative breast carcinomas. Am J Clin Pathol 2011; 135: 230 7.

25. Hiroko Y, Mariko N, Toyama T, Sugiura H, Zhang Z, Kobayashi S et al. Coexistence of HER2 over-expression and p53 protein accumulation is a strong prognostic molecular marker in breast cancer. Breast Canc Res 2004, 6: R24-R30.

26. Ha JH, Seong MK, Kim EK, Lee JK, Seol H, Lee JY et al. Serial serum HER2 measurements for the detection of breast cancer recurrence in HER2-positive patients. J Breast Cancer 2014; 17: 33-9.

27. Cooke T, Reeves J, Lanigan A, Stanton P. HER2 as a prognostic and predictive marker for breast cancer. Ann Oncol 2001; 12: S23-S28.

28. Bloom HJ, Richardson WW. Histological grading and prognosis in breast cancer. Br J Cancer 1957; 11: 359-77.

29. Elston CW. Grading of invasive carcinoma of the breast. In: Diagnostic histopathology of the breast. Page D.L. and Anderson T.J. (Edinburgh. Churchill Livingstone 1988; 303-311.

30. Joensuu K, Leidenius M, Kero M, Andersson LC, Horwitz KB, Heikkilä P. ER, PR, HER-2, Ki67 and CK5 in early and late relapsing breast cancer-Reduced CK5 expression in metastasis. Breast Cancer: Basic Clin Res 2013; 7: 23-34

31. Golmohammadi R, Pejhan A. Gene experison of cell proliferative marker Ki67 in breast cancer. J Gorgan Univ Med Sci 2011; 13: 65-71.

32. Mousavi M, Mohebi H, Teimouri M, Lalouli A. Relation between Ki67, Her-2 neu, ER and PR marker with age in breast cancer patients. Iranian J Breast Dis 2010; 3: 8-17.

33. Moriya T, Sakamoto K, Sasano H, Kawanaka M, Sonoo H, Manabe T et al. Immunohistochemical analysis of Ki-67, p53, p21, and p27 in benign and malignant apocrine lesions of the breast: its correlation to histologic findings in 43 Cases. Mod Pathol 2000; 13: 13.

34. Gurzu S, Jung J, Mezei T, PavaiI Z. The correlation between the immunostains for p53 and Ki67 with bcl-2 expression and classical prognostic factors in colorectal carcinomas. Rom J Morphol Embryol 2007; 48: $95-99$.

35. Sirvent JJ, Salvadól MT, Santafé M, Martinez S, Brunet J, Alvaro T et al. p53 in breast cancer. Its relation to histological grade, lymph-node status, hormone receptors, cell-proliferation fraction (ki-67) and c-erbB-2. Immunohistochemical study of 153 cases Histol Histopathol 1995; 10: 531-9.

36. Kankuri M, Soderstrom K, Pelliniemi TT, Vahlberg T, Pyrhonen S, Salminen E. The association of immunoreactive p53 and Ki-67 with T-stage, grade, occurrence of metastases and survival in renal cell carcinoma. Anticanc Res 2006; 26: 3825-34.

37. Hegazi A, Hassan E, El-Atrebi KA, El-Bassyouni HT. P53 protein and $\mathrm{Ki}-67$ expression in chronic gastritis patients with positive Helicobacter pylori infection. J Genet Eng Biotechnol 2011; 9: 73-6.

38. Maggie CU, Cheang SK, Chia DV, Gao D, Leung S, Snider J. Ki67 Index, HER2 Status, and Prognosis of Patients with Luminal B Breast Cancer. J Natl Cancer Inst 2009; 101: 736- 50.

39. Mylonas I, Makovitzkyudo J, Briese J, Friese GB. Expression of Her2/neu, steroid receptors (ER and PR), Ki67 and p53 in invasive mammary ductal carcinoma associated with ductal carcinoma in situ (DCIS) versus invasive breast cancer alone. Anticanc res 2005; 25: 1719-24.

40. Chan Y, Chen B, Chang CH, Long YT, Fan CH. Expression of p53 Protein and Ki-67 Antigen in Phyllodes Tumor of The Breast. JCMA 2004; 67: $3-8$. 